\title{
VIII. Memoir on the anatomy of vegetables. Read before the Physical Class of the Institute
}

\section{Mirbel}

To cite this article: C. Mirbel (1802) VIII. Memoir on the anatomy of vegetables. Read before the Physical Class of the Institute, Philosophical Magazine Series 1, 13:49, 36-40, DOI:

$10.1080 / 14786440208676087$

To link to this article: http://dx.doi.org/10.1080/14786440208676087

曲 Published online: 18 May 2009.

Submit your article to this journal $\sqsubset \pi$

Џ Article views: 2

Q View related articles $\square$ 
ftone that it feems to form one body with it, no mineralogift can with certainty explain.

The hypothefis which I bave ventured to form of this fingular and certainly uncommon fubterranean mixture is, that the charcoal was burnt in the neighbourhood either in the ufual manner or by natural fire, and that fome fragments of it, by fome convulfion of nature, were thrown to the above depth, where they united with the ferruginous matter, and by thefe means produced the above remarkable phrnomenon. On many fragments one can obferve the tranfition of the not completely burnt wood into iron-ftone; even the bark of the wood, actually converted into iron-ftone, may be clearly diftinguifhed; and the perfectly black natural or artificial charcoal, poffeffing all the properties of the charcoal of burnt wood, lies undecompofed in it: but it would be worth while to fubject it to a more accurate chemical refearch, in order to examine its component parts. I hope to obtain, by one of my friends, a morc detailed account of this fubterranean phrnonenon; and therefore I fhall only add at prefent, that this iron-ftone is exceedingly eafy of fufion, and fo much fo, that it is ufed as a flux for other kinds, and, in fome meafure, indifpenfably neceffary at the forges, efpecially when caft articles are to be manufactured with advantage.

VIII. Memoir on the Anatomy of Vegetables. Read before the Pbyfical Clajs of the Inflitute by C. MI B B L *.

\section{Of the Elementary Organs.}

AfTER ftudying the works of Dubamel, Senebier, De
Saufture, and feveral other philofophers, without being able
to form any fixed opinion of the internal anatomy of vege-
tables, it appeared to me that it would be more advantageous
to ftudy nature in her own works. I endeavoured to banifh
from my nind every thing fyftematic, in order that my ob-
fervations might be free from every kind of bias. All vege-
tables have too much relation in the mode of the develop-
ment of their organization not to exhibit great fimilitude.
This reflection, which naturally prefents itfelf to the mind,
induced me to direct my firt obfervations to one fpecies. I
made choice of the elcer, as having a loofer texture, and
eafier to be obferved, than that of many other vegetables.
During fix months, I cmployed all the known procefles for
;F From the foumal se Pby/fque, Germinal, an. 10 . acquiring 
acquiring a knowledge of the organs of that plant. I ufed comparatively four or five different microfcopes; and, when I fuppofed that I had got the whole feries of facts, I tried the fame obfervations on a great number of other vegetables. The comparifons I then made greatly contributed to give me information refpecting the nature and form of the organs; and to obviate, by every mean poflible, the illufions which might lead me into a falfe path, I begged C. Mafey, my friend and fellow-labourer, to revife my obfervations, and to examine them with the fevereft criticifm. His obfervations compared with mine have either confirmed or rectified them.

I fhall now give a defcription of the parts which I call elementary organs, becaule all the other organs are compofed of them.

\section{Cha P. I.}

\section{Of thofe Parts wbicb are difing uifbed by the naked Eye.}

Vegetables in general are compofed, as every body may have obferved, of foft and hard parts. Some, indeed, fuch as muhrooms and fuci, feem to be formed entirely of a homogeneous fubftance, pretty foft; but this clafs is not very numerous.

The ftem of the moft perfect plants prefents at its furface a coloured fubitance of greater or lefs thicknefs, which is the bark. It adheres ftrongly to the interior parts in a great many of the monocotyledons, and fometimes even is confounded and connected with them in fuch a manner that it is imporfible to diftinguifh them. It may in this cafe be faid that no bark exifts. This phænomenon is obferved in the palms, gramineous plants, \&ce. But in the dicotyledons and fome monocotyledons the bark, very dittinct from the reft of the tiffue, forms an exterior ftratum, which may be eafily detached.

Below the bark is found the wood more compact, harder, and more connected in all its parts, and which feems to be formed of longitudinal fibres ftrongly cemented to each other. In the monocotyledons without bark there is found, immediately below the epidernis, a fine tranfparent membrane, which is the exterior part of the vegetable.

The wood, as the learned Desfontaines has faid in his excellent memoir on the Comparative Anatomy of Vegetables, is diftributed lengthwife in the ftem and branches of the monocotyledons in delicate threads: thefe threads are often parallel, and fometimes convergent one towards the other; they unite one and one, two and two, or divide themfelves, and become ramified in threads of ftill greater finenefs. All $\mathrm{C}_{3}$ 
thefe threads are furrounded with a foft, elaftic, fpongy fubftance, eafily torn, and generally whitih, which is called the pith, and to which I thall give the name of parencbyme, that it may not be confounded with the pith of the dicotyledon plants. The wood of the latter, lying always under the bark, is not divided into diftinet threads; it generally forms a cylinder, in the centre of which is placed the pith, as in a cafe. Some plants, however, evidently furnifhed with two cotyledons, exhibit ligneous filaments fimilar to thofe of the monocotyledons, running along the whole length of the medulJary canal: but thefe are exceptions which do not deftroy the general ru\}e.

In trees or fhrubs with two cotyledons there are almoft always obferred diftinet lines of the wood, which proceed from the pith, traverfe the ligneous cylinder, and end at the bark. They appear on the tranfverfal fection of the trunk, ftem, branches, and twigs, like the hour-lines of a dial. They are called the medullary radii. They feldom fhow themfelves in the ftems of the dicotyledon herbs, and do not exift in the monocotyledons either herbaccous or ligneous.

In the leaves, flowers, pericarpia, \&c. there are found alfo parts of greater or lefs foftnefs, and greater or lefs hardnefs, the fubftance of which appears to be fimilar to the bark, pith, or wood.

Such are the different parts which vegetables exhibit to the naked eye. We muft now examine the elementary organs which enter into their compofition.

$$
\begin{gathered}
\text { Снар. II. } \\
\text { Of the Membranous Tiffue. }
\end{gathered}
$$

Vegetables are compofed of a membranous tiffue, which varies in its form and confiftence, not only in the different fpecies, but even in the fame individual. I thall not here examine whether the membranes are compofed of organic fibres, ranged clofe to each other and united by a gluten, as fome authors affert. This fuppofition is fufceptible neither of ftrict demonftration, nor a formal refutation ; it is one of thofe fyftems which amufe the mind when refearch becomes fruitlefs. I hlall content myfelf with ftating, that, whatever may have been the perfeverance of my obfervations, I never obferved real fibres in vegetables; the filaments to which that name has been given are only membranes, which tear into longitudinal ftripes: fuch were the delicate filaments which Dubamel feparated from a bit of wocd which he obferved through the microfcope.

The membranous tiffue, though continued in all its parts, 
forms two kinds of different organs; the cellular tiffue, and the tubular tiffue.

\author{
Chap. III. \\ Of the Cellular Tiffue.
}

This tiffue prefents to the obferver a feries of membranous bags, which on the firft view feem to have no communication with each other. They are not fmall bladders or utriculi, as moft authors affert; they are a membrane, which bends itfelf, in fome meafure, to form vacuities contiguous to each other. In the parts where thefe cells experience no foreign preffure, they are all equally dilated, their tranfverfal and vertical fections prefent hexagons fimilar to the alveolæ of bee-hives; each fide of thefe geómetrical figures is common to two cells, and the whole tiffue is wonderfully regular: but, when the tiffue is compreffed, the hexagons lofe their thape, and are converted fometimes into parallelograms more or lefs elongated. The membranous fides of the cells are exceedingly thin and colourlefs : they are tranfparent like glafs, and their organization is fo delicate, that it cannot be perceived even with the help of the molt powerful microfcopes. They are generally filled with pores, the apertures of which do not certainly exceed the 3 ooth part of a line; thefe pores are bordered with fmall unequal and glandulous rolls, which intercept the light, and refract it with force when they receive its rays. The cellular tiffue is fpongy, elaftic, and without confiftence; when immerfed in water it becomes altered, and, in a little time, is even deftroyed: it is then reduced to a kind of mucilage. Thefe pores eftablifh a communication between one cell and another, and ferve for the transfufion of the juices in that tiffue, which is exceedingly flow. I mult alfo obferve, that it is not a conduEtor of the fluids diffufed throughout the vegetable, and that it produces nothing of itfelf.

I have faid that the membranes are tranfparent and colourlefs: when the tiffue is difengaged from every foreign body, this is true; but it is often marked by colouring fubftances, which tarnith its tranfparency. This tiffue exilts in all vegetables, but not in the fame proportion. Mufhrooms and fuci appeared to me to be compofed only of cellular tiffue. The bark of monocotyledons and dicotyledons is almoft entirely formed of it: in thefe, it is generally fomewhat compreffed between the epidermis and the wood; it is filled with refinous juices, commonly coloured green, but fometimes red or yellow, according to the nature of the vegetable. This gives different tints to the epidermis, which is nothing $\mathrm{C}_{4}$ elle 
elfe than the exterior fide of the firft row of cells, as the illuftrious Malphigi fuppofed. The pith in all plants is compofed of hexagonal cells. In herbaceous plants, and particularly thofe which are highly fucculent, thefe cells are often filled with juices more or lefs thick or coloured. In ligneous plants, naturally drier, they are, on the other hand, almoft entirely empty, and tranfparent. The cellular tiffue in bulbous roots is pulpy and fucculent; in the cotyledons it is hard and brittle; and in the albumen and feeds it is dry and arid. The parenchyme of the leaves, of the bractex, $\mathrm{At} i-$ pulæ, and calyces, is formed by cells filled with a juice almoft always coloured, and green. The rich corollæ, which difplay to the light the elegance of their forms and the fplendour of their colours, but of which the beauty and frefhnefs vanifh in a moment, are not fo thin as the delicate membranes of the cellular tiffue : the juices which fwell the tranfparent utriculi of which they are formed give them thefe colours; the one fometimes diffufed into the other by imperceptible tints, fometimes abruptly oppofed, and heightening their fplendour by the contraft. Here the cellular tiffue is fo delicate, that the flighteft touch is fufficient to alter and tarnifh it: the leaft preffure reduces it to mucilage, and it appears to be the momentaneous product of the air and water. This tiffue is obferved alfo in the ftamina and the piftils. The pollen, that fine duft which contains the fubtile fluid neceffary for fecundation, appears to be only an accumulation of fmall bags formed of the cellular tiflue: in a word, it is this tiffue which, by dilating itfelf, produces fucculent fruits.

The cells are proportionally more abundant in herbs than in trees, and in young fhoots than in old timber. The embryo is compofed almoft entirely of cellular tiffue. The medullary radii, which extend from the centre to the circumference in the trunks and branches of trees with two cotyledons, are fometimes alfu nothing but a thin membrane of cells, [To be continued.]

IX. Metbod of wbitening the Gray Marine Salt to fit it for domeftic Purpojis inftantaneoufly, and without the Aid of Heat. By Pajot Descharmes*.

G

TRAY or unrefined marine falt, as every body knows, is covered with a tihn earthy cruft which alters more or lefs its whitenefs; and it is a matter of fome confequence, both in

* From the fame. regard 